\title{
US radiation report fails to satisfy critics
}

Washington. Groups representing individuals who were the subject of human radiation experiments in the United States after the Second World War have reacted angrily to the main findings of the Presidents' Advisory Committee on Human Radiation Experiments, which reported to President Bill Clinton last week.

The groups, broadly represented by a body known as the Task Force on Radiation and Human Rights, have attacked the report - prepared by a panel chaired by Ruth Faden of Johns Hopkins University in Baltimore, Maryland - for failing to recommend any medical follow-up to the experiments, or compensation for subjects who are unable to prove that they experienced physical harm.

Geoffrey Sea, a health physicist based in Oakland, California, and the West Coast coordinator of the task force, describes the report as "absolutely inadequate". Similarly, David Egilman, an assistant clinical professor at Brown University, Rhode Island, an outspoken critic of the radiation experiments, says that the advisory committee did "an abysmal job".

It was complaints from members of the task force that initially led Hazel O'Leary, the energy secretary, to initiate the process that culminated in last week's report. The task force is now planning to formally reject an apology that was issued by Clinton when the report was released (see Nature 377,$374 ;$ 1995).

Clinton had offered "sincerest apologies to those citizens, their families and their communities" on behalf of the US government. But the activists want cash compensation for thousands of people unknowingly subjected to the experiments.

They also want all such experimental subjects to be formally notified of what happened, and to be offered medical followup. The advisory committee ruled that cash compensation would be morally out of proportion to the original wrong, and that it was now too late for any useful follow-up.

Some of the group's concerns are shared by politicians who have supported the subjects' cause, such as Senator John Glenn (Democrat, Ohio). After the report was released, Glenn called for "a limited medical monitoring programme" to follow up the experiments.

Responding to the committee's finding that existing protections for human research subjects are "seriously deficient", Clinton asked all the federal agencies involved to review procedures for protecting the subjects of experiments, and to report back within three months to the planned National Bioethics Advisory Commission (NBAC), which he also announced last week. The NBAC's members have not yet been named.

The Secretary of Health, Donna Shalala, whose department conducts most US research on human subjects through the National Institutes of Health, said that she accepted the criticism of existing protective procedures. "We accept the fundamental premise that significantly more needs to be done" to protect human subjects, she said.

Colin Macilwain

\section{Protest over spent fuel shipment highlights storage crisis}

London. Anti-nuclear activists last week attempted to block the shipment of 52 spent fuel rods from a research reactor in Germany to a reprocessing facility at the UK Atomic Energy Authority's Dounreay plant in Scotland.

Protesters from the environmentalist group Greenpeace managed to delay the shipment from the German port of Bremerhaven for several hours by chaining themselves to containers holding the fuel rods. A demonstrator was arrested two days later when the shipment, from the Hahn Meitner Institute (HMI) in Berlin, was unloaded in the port of Scrabster near Dounreay.

The decision to send the spent fuel to Scotland - rather than the United States, where it originated - follows similar protests last year from local groups in South Carolina, where the fuel rods had previously been scheduled to be reprocessed under a US-German agreement.

The latter agreement followed an earlier decision taken by the United States in 1978, under which it promised to take back spent, high-enriched uranium (HEU) fuel of US origin - concerned that this could be used to produce plutonium for weapons - from countries promising to convert their reactors to low-enriched uranium (LEU).

French nuclear tests: A recent article (see Nature 377, 186; 1995) on an exchange in the French press about the significance of the nuclear tests in the South Pacific should have mentioned that this exchange was published in the newspaper Libération.
A court decision in South Carolina forced a delay in any decision over the eventual fate of the fuel rods until the completion of an environmental impact statement by the Department of Energy (DoE) (see Nature 376, 716; 1995). The outcome of the assessment will be announced later this month.

But the delay has left research reactors throughout Europe near the limits of their storage capacities. It was this crisis that forced the HMI to sign the Dounreay contract.

Despite local opposition, the UK Department of Trade and Industry (DTI) is keen for the United States to fund reprocessing at Dounreay to keep the plant, a likely victim of the virtual collapse of interest in fast breeder reactors, in business over the next ten to fifteen years.

The US impact statement is expected to consider disposal at Dounreay as an alternative option to that preferred by the US government, namely reprocessing at the DoE's facilities in North Carolina. But Mike Townsley of Greenpeace points out that, while three major public consultations have taken place in the United States about what should be done with the waste from reactors using HEU, "nobody has bothered to ask the Scottish people what they want".

Local concern in Scotland is focused on the possible increase in radioactive emissions from Dounreay resulting from any new contracts. One reprocessing plant is already engaged at full capacity in decommissioning the reactor core of Dounreay's Prototype Fast Reactor (PFR). The small shipment from Germany, along with a much smaller one from a Scottish reactor, will require the reopening of a second plant, the Materials Testing Reactor (MTR) reprocessing plant, in January.

According to Lorraine Mann, of the protest group Scotland Against Nuclear Dumping, the United States, under the terms of its nuclear anti-proliferation policy, is prevented from endorsing the opening of such a reprocessing facility, as that would keep the plutonium in circulation.

Anti-proliferation groups in the United States, such as the Nuclear Control Institute, remain concerned that European deals such as that between the HMI and the UK Atomic Energy Authority may encourage trade in weapons-grade fuel.

Meanwhile participants attending a meeting in Paris last month endorsed a letter to President Clinton expressing their concern that the 1978 agreement may now be in danger of collapse. The letter cites in particular the apparent lapsing of the United States' agreement to take back spent fuel, and the suspension of US support for the development of high-density LEU fuel at the Argonne National Laboratory.

The letter diplomatically avoids direct mention of the planned FRMII reactor, the first designed to burn HEU since the start of the 1978 agreement. At the Paris meeting, representatives from Argonne put forward an alternative design that would allow highdensity LEU fuel to be used in the reactor. But the Technical University of Munich has rejected suggestions of a redesign.

Ayala Ochert \& Alison Abbott 